\title{
PENGUKURAN DOSIS EFEKTIF ORGAN TYROID DAN MATA PADA PEMERIKSAAN MAMMOGRAFI
}

\author{
Lody Firmansyah, Febria Anita \\ Jurusan Fisika Fakultas Teknik dan Sains Universitas Nasional Jakarta \\ Email:febria.anita85@gmail.com
}

\begin{abstract}
A research has been done about the effective dose measurement of thyroid and eye organ on mammography examination. The aims of the research is to determine the radiation dose absorbed by the thyroid organ and eye examination Mammography. This research uses TLD-100 as a radiation measuring instrument. The data retrieval process has taken place in Parahita Laboratorium, Jakarta by collecting five of patients data to have Mammography radiology examination, the research is done by putting the TLD-100 in every side of thyroid organ and eye to know the value radiation dose which occurs in Mammography examination. Eksposi factors used in this study was $29 \mathrm{kV}$ and $250 \mathrm{~mA}$. The result of this research is obtained the value of the dose absorbed by the thyroid organ and less than the limit value of existing dose of $0,7 \mathrm{mSv}$, To analysts equivalent dose in patients who received organ Mammography is quite safe because less than the value standard dose limits specified.
\end{abstract}

Key words : mammography, radiation dose, TLD

\section{PENDAHULUAN}

Kelenjar tyroid adalah salah satu dari kelenjar endokrin terbesar pada tubuh manusia. Kelenjar ini dapat ditemui di bagian depan leher, sedikit di bawah laring. Kelenjar ini berfungsi untuk mengatur kecepatan tubuh membakar energi, membuat protein, dan mengatur sensitivitas tubuh terhadap hormon lainnya[1].

Tiroid mengeluarkan dua hormon penting, yaitu: Triodotironin dan Tiroksin. Hormon ini berfungsi mengatur laju metabolisme dengan cara mengalir bersama darah dan memicu sel untuk mengubah lebih banyak glukosa. Jika Tiroid mengeluarkan terlalu sedikit Triodotironin dan Tiroksin (Hipotiridisme), maka tubuh akan merasa kedinginan, letih, kulit mengering dan berat badan bertambah. Sebaliknya jika terlalu banyak (Hipertiroidisme), tubuh akan berkeringat, merasa gelisah, tidak bisa diam dan berat badan akan berkurang. Mata adalah organ penglihatan yang mendeteksi cahaya. Yang dilakukanmata yang paling sederhana tak lain hanya mengetahui apakah lingkungan sekitarnya adalah terang atau gelap. Mata yang lebih kompleks dipergunakan untuk memberikan pengertian visual[2]. Mata manusia memiliki cara kerja otomatis yang sempurna, mata dibentuk dengan 40 unsur utama yang berbeda dan ke semua bagian ini memiliki fungsi penting dalam proses melihat kerusakan atau ketiadaan salah satu fungsi bagiannya saja akan menjadikan mata mustahil dapat melihat. Lapisan tembus cahaya di bagian depan mata adalah kornea, tepat dibelakangnya terdapat pupil, fungsi dari pupil sendiri adalah untuk mengatur intensitas cahaya yang masuk ke mata. Selain pupil ada juga bagian mata yang disebut selaput pelangi, fungsinya adalah memberi warna pada mata, selaput pelangi juga dapat mengubah ukuran pupil secara otomatis sesuai kekuatan cahaya yang masuk, dengan bantuan otot yang melekat padanya.

Mammografi adalah proses pemeriksaan payudara manusia menggunakan sinar- $X$ dosis 
rendah (umumnya berkisar $0,7 \mathrm{mSv}$ ). Mammografi digunakan untuk melihat beberapa tipe tumor dan kista, dan telah terbukti dapat mengurangi mortalitas akibat kanker payudara. Selain mammografi, pemeriksaan payudara sendiri dan pemeriksaan oleh dokter secara teratur merupakan cara yang efektif untuk menjaga kesehatan payudara. Beberapa negara telah menyarankan mammografi rutin (1-5 tahun sekali) bagi perempuan yang telah melewati paruh baya sebagai metode screening untuk mendiagnosa kanker payudara sedini mungkin.

Sebagaimana penggunaan sinar-X lainnya, mammogram menggunakan radiasi ion untuk menghasilkan gambar. Radiolog kemudian menganalisa gambar untuk menemukan adanya pertumbuhan yang abnormal. Walaupun teknologi mammografi telah banyak mengalami kemajuan dan inovasi, ada komunitas medis yang meragukan penggunaan mammografi karena tingkat kesalahan yang masih tinggi dan karena radiasi yang digunakan dapat menimbulkan bahaya. Jaringan apabila terkena radiasi sinar-X, akan menyerap energi radiasi dan akan menimbulkan ionisasi atom-atom. Ionisaisi tersebut dapat menimbulkan perubahan kimia dan biokimia yang pada akhirnya akan menimbulkan kerusakan biologis. Kerusakan sel yang terjadi itu dapat berupa kerusakan kromosom, mutasi, perlambatan pembelahan sel dan kehilangan kemampuan untuk berproduksi [3]. Organ tyroid dan mata merupakan salah satu organ kritis yang berada di dekat mammae sehingga berisiko menerima paparan radiasi. Pada penelitian ini akan diteliti dosis efektif yang terserap pada organ tyroid dan mata pada pemeriksaan mammografi dikarenakan organ tersebut sangat sensitif terhadap radiasi, maka diperlukan adanya penelitian terhadap nilai dosis serap radiasi hambur yang dikenai organ tersebut.

\section{METODE PENELITIAN}

Penelitian yang bersifat eksperimental dimana peneliti melakukan eksperimen langsung untuk mengukur dosis serap radiasi organ thyroid dan mata pada pemeriksaan Mammografi. Pada penelitian ini menggunakan pesawat mammografi merk GE Senographe DMR yang ada di Ruangan Radiologi Laboratorium Parahita Jakarta. Alat ini Telah di kalibrasi dan untuk memperkirakan dosis radiasi yang diterima dari sumber radiasi digunakan 20 buah TLD-100. Serta bahan yang digunakan dalam penelitian ini adalah 5 pasien yang disiapkan untuk pemeriksaan mammografi sebagai objek penelitian. Pesawat mammografi merk GE modelSENOGRAPHE DMR milik Laboratorium Parahita Jakarta dengan no seri 2144552-100 memiliki kapasitas maximal 49 $\mathrm{kV}$ dan $600 \mathrm{~mA}$ seperti Gambar 1 dan untuk TLD nya dapat dilihat pada gambar 2 .

Data yang akan dianalisa dalam penelitian ini adalah hasil analisis dan pengukuran dosis radiasi yang terserap oleh Thermoluminiscent Dosimeter (TLD) terhadap nilai dosis radiasi pada pasien pemeriksaan Mammografi dengan mengukur nilai dosis radiasi yang tertera pada Thermoluminiscent Dosimeter (TLD). Kemudian, pengukuran nilai dosis serap dilakukan dengan proses pembacaan hasil Thermoluminiscent Dosimeter (TLD) dengan menggunakan TLD reader khusus untuk pembacaan nilai hasil Thermoluminiscent Dosimeter (TLD), TLD reader mengubah intensitas cahaya menjadi sinyal yang diukur dengan ukuran satuan nC (nano coulomb). Pengukuran dilakukan sebanyak dua kali proses untuk TLD. Pengukuran pertama adalah membaca intensitas termoluminisensi total, sedangkan pengukuran kedua adalah membaca intensitas termoluminisensi latar. Intensitas termoluminisensi bersih merupakan hasil pengurangan intensitas termoluminisensi total dengan intensitas latar. Perhitungan dosis radiasi (D) yang diterima TLD dilakukan dengan formula sebagai berikut:

$$
\mathrm{D}=\mathrm{TL}(\mathrm{nC}) \mathrm{x} \mathrm{Fk}(n C \cdot S v) \ldots \ldots .1)
$$


Firmansyah, L., \& Anita, F. 2016. Pengukuran Dosis Efektif Organ Tyroid dan Mata Pada Pemeriksaan Mammografi. Journal of Sainstek 8(1): 31-37

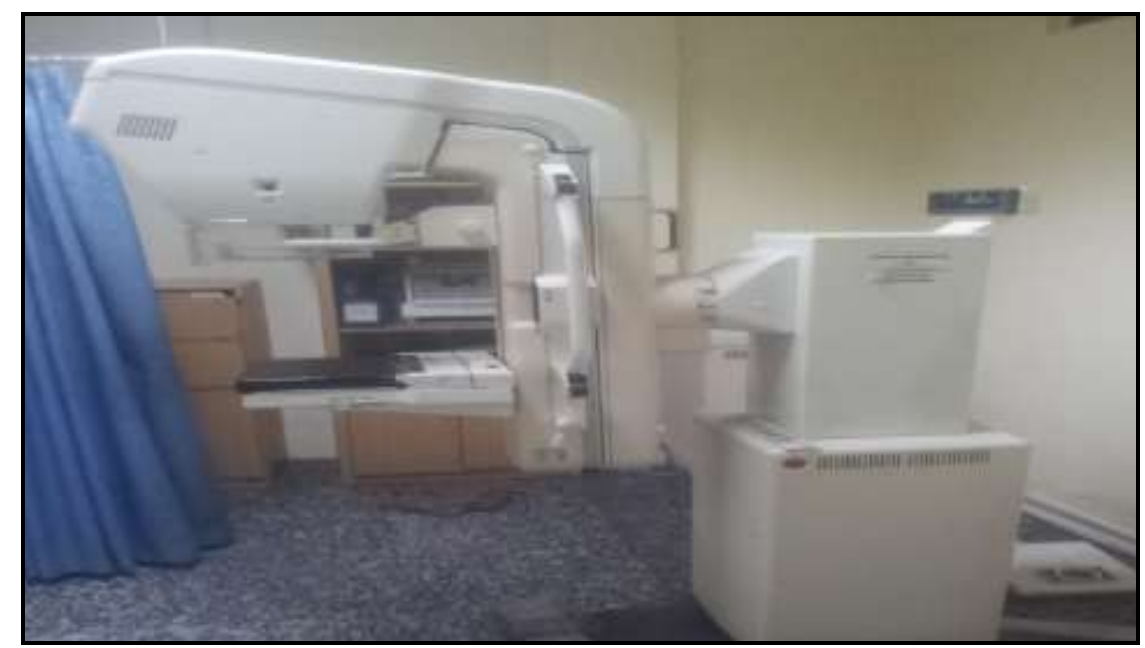

Gambar 1 Pesawat Mammografi milik Parahita (Dokumen Pribadi)

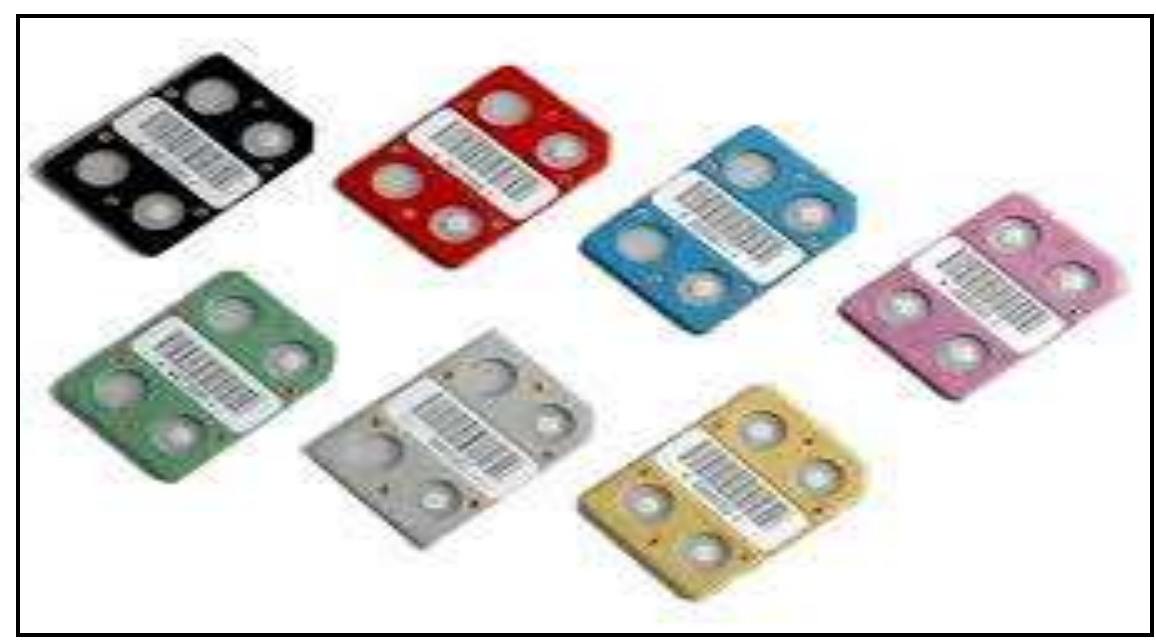

Gambar 2 Thermoluminiscent Dosimeter (TLD) (Dokumen Pribadi)

Pembacaan nilai hasil Thermoluminiscent Dosimeter (TLD) dilakukan di BPFK. kemudian hasilnya dibuat tabel dan grafik untuk dianalisa yang kemudian akan digunakan untuk membandingkan nilai dosis serap dengan standar yang berlaku. Pemeriksaan Mammografi menggunakan tegangan tabung 29 $\mathrm{kV}$ biasanya disebut dengan teknik standar atau teknik tegangan rutin. Dalam penelitian ini hendak diperoleh dosis radiasi yang terserap oleh organ mata dan thyroid untuk di amati dan dibandingkan dengan dosis toleransi yang berlaku untuk kedua organ tersebut pada pemeriksaan radiografi Thorax menggunakan
Computed Radiography (CR) dan Thermoluminiscent Dosimeter (TLD) sebagai alat untuk mengetahui nilai dosis serap yang terjadi selama pemeriksaan berlangsung.

Objek dalam penelitian ini yaitu pasien wanita berjumlah 5 orang Berikut prosedur dalam pengambilan data untuk penelitian ini :

I. Persiapan Pemeriksaan

Pasien yang akan menjalani pemeriksaan disiapkan terlebih dahulu lalu masing-masing pasien di tempelkan Thermoluminiscent Dosimeter (TLD) disekitar leher dan mata.

2. Pengaturan posisi pasien 
Firmansyah, L., \& Anita, F. 2016. Pengukuran Dosis Efektif Organ Tyroid dan Mata Pada Pemeriksaan Mammografi. Journal of Sainstek 8(1): 31-37

Dalam melakukan pemeriksaan, maka posisi pasien perlu diatur sedemikian rupa, sehingga memudahkan pelaksanaan pemeriksaan pada bagian yang diperlukan. Posisi pasien merupakan letak atau kedudukan pasien secara keseluruhan dalam suatu penyinaran. Posisi pasien ini bervariasi bergantung dari jenis pemeriksaan yang diminta, salah satu contoh yaitu proyeksi mediolateral $(M L O)$ craniocaudal $(C C L)$.

3. Pengaturan faktor exposure

Faktor exposure atau penyinaran terdiri dari tegangan tabung $(\mathrm{kV})$, arus $(\mathrm{mA})$ dan waktu penyinaran (s). Pengaturan faktor exposure ini terdapat di control table pesawat mammografi .

4. Mencatat faktor eksposi dan posisi yang diberikan pada pasien

\section{HASIL DAN PEMBAHASAN}

Setelah dilakukan penelitian dan penghitung nilai dosis yang tertera di Thermoluminiscent Dosimeter (TLD) lalu dilakukan perhitungan dosis ekivalen dan dosis ekivalen efektif didapatkan hasilnya seperti dalam tabel 1 dan di peroleh grafiknya pada gambar 3 .

Tabel 1. Hasil Perhitungan Dosis Efektif

\begin{tabular}{cccccc}
\hline NO & Organ & Proyeksi & $\begin{array}{c}\text { Jumlah } \\
\text { Data }\end{array}$ & $\begin{array}{c}\text { Nilai Rata-Rata Dosis } \\
\text { Ekivalen }(\mathrm{mSv})\end{array}$ & $\begin{array}{c}\text { Nilai Rata-Rata Ekivalen } \\
\text { Efektif (mSv) }\end{array}$ \\
\hline 1 & Mata & Medio Lateral & 5 & 0,04 & 0,012 \\
2 & Mata & $\begin{array}{c}\text { Cranio Caudal } \\
\text { Cranio }\end{array}$ & 5 & 0,03 & 0,009 \\
3 & Tyroid & Medio Lateral & 5 & 0,03 & 0,001 \\
4 & Tyroid & Cranio Caudal & 5 & 0,04 & 0,001 \\
\hline
\end{tabular}

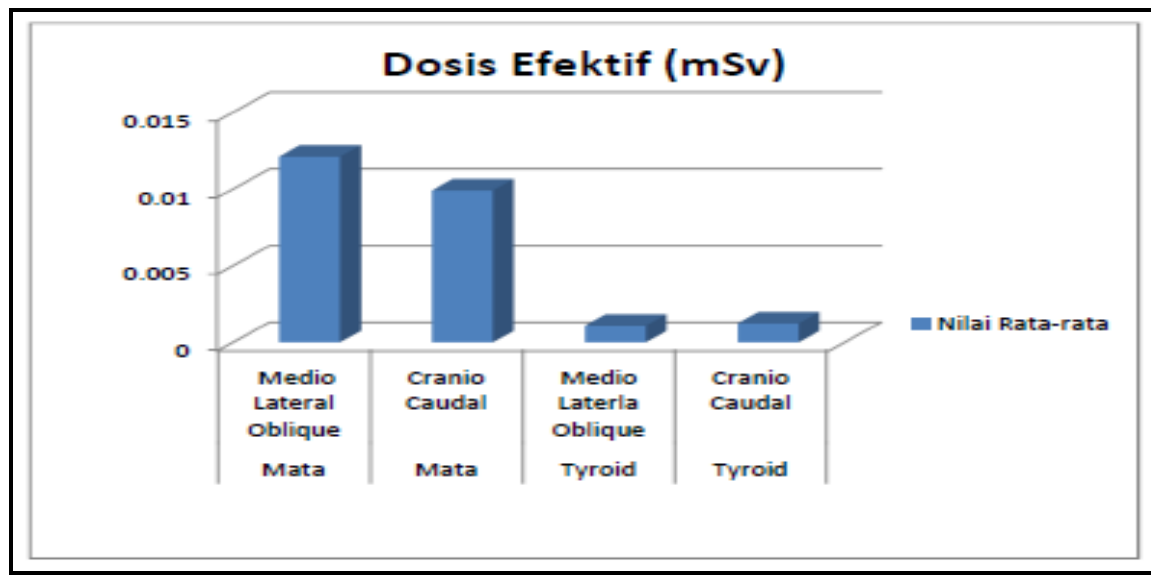

Gambar 3 Grafik Hasil Perhitungan Dosis Efektif

Berdasarkan hasil perhitungan data penelitian yang telah dilakukan, terlihat bahwa nilai hasil dosis efektif yang terpapar pada sekitar organ mata dan Tyroid baik pada proyeksi Medio lateral Obelique hingga proyeksi cranio caudal didapat hasil yang 
Firmansyah, L., \& Anita, F. 2016. Pengukuran Dosis Efektif Organ Tyroid dan Mata Pada Pemeriksaan Mammografi. Journal of Sainstek 8(1): 31-37

beragam antara $0,001 \mathrm{mSv}$ hingga $0,012 \mathrm{mSv}$. Hasil tersebut bila dibandingkan dengan dosis toleransi yang ditetapkan oleh PERKA BAPETEN NO.8 Tahun 2011 maka nilai ratarata tersebut dikategorikan masih dalam batas toleransi aman bagi masyarakat umum. Dari hasil nilai tersebut diketahui bahwa nilai dosis efektif yang terpapar pada organ mata proyeksi medio lateral obelique didapatkan ratarata nilai dosis efektif adalah 0,012 mSv. Kemudian pada organ mata proyeksi cranio caudal didapatkan nilai rata-rata dosis efektif adalah $0.009 \mathrm{mSv}$, serta pada organ tyroid proyeksi medio lateral obelique didapatkan nilai rata-rata dosis efektif adalah $0,001 \mathrm{mSv}$. Dan pada organ tyroid proyeksi cranio caudal didapatkan nilai ratarata dosis efektif yang terpapar adalah sebesar 0,001 mSv. Dari hasil tersebut diketahui bahwa nilai rata -rata dosis efektif yang terpapar dikategorikan masih dibawah dari standar yang ada yaitu Dosis ekivalen untuk lensa mata sebesar $15 \mathrm{mSv}$ (lima belas mili sievert) serta untuk semua organ (tyroid) adalah sebesar 50 $\mathrm{mSv}$ (limapuluh milisievert) untuk masyarakat umum dalam hal ini adalah pasien. Hasil tersebut merupakan standar dalam Peraturan Kepala Badan Pengawas Tenaga Nuklir Nomor 8 Tahun 2011.

Dari hasil nilai tersebut diketahui bahwa nilai dosis efektif yang terpapar pada organ mata proyeksi medio lateral obelique didapatkan ratarata nilai dosis efektif adalah $0,012 \mathrm{mSv}$. Kemudian pada organ mata proyeksi cranio caudal didapatkan nilai ratarata dosis efektif adalah $0.009 \mathrm{mSv}$, serta pada organ tyroid proyeksi medio lateral obelique didapatkan nilai rata-rata dosis efektif adalah $0,001 \mathrm{mSv}$. Dan pada organ tyroid proyeksi cranio caudal didapatkan nilai rata-rata dosis efektif yang terpapar adalah sebesar $0,001 \mathrm{mSv}$. Dari hasil diatas terlihat bahwa nilai dosis ekivalen yang terpapar pada organ tyroid maupun organ mata didapatkan nilai dosis yang tidak jauh berbeda baik pada proyeksi Medio Lateral Obelique (MLO) maupun proyeksi Cranio Caudal (CCL), namun untuk nilai dosis ekivalen efektif yang didapat terlihat perbedaan yg cukup besar antara organ tyroid dan mata. Hal ini disebabkan oleh adanya perbedaan faktor bobot organ yang telah ditetapkan oleh Surat Keputusan Kepala BAPETEN No. 01/V. Tahun1999.

Dalam hasil tersebut didapatkan nilai dosis efektif yang cenderung kecil dikarenakan dosis yang dihasilkan merupakan hasil ketika sinar-X menembus objek jadi hasil dosis yang tertera kecil, karena sinar $X$-Ray sendiri memiliki sifat yaitu apabila menembus objek akan mengalami atenuasi (pelemahan) sehingga hasil nilai dosis efektif setelah menembus objek terserap oleh objek sebagian dan sinar-X yang menembus objek nilainya menjadi lebih kecil. Penggunaan faktor eksposi harus menghasilkan penerimaan dosis radiasi pada pasien yang seminimal mungkin sesuai dengan prinsip ALARA (As Low As Reasonably Achieveble), pemanfaatan sumber radiasi selalu menghendaki adanya penerimaan dosis yang serendah mungkin terhadap pasien, pekerja radiasi maupun masyarakat [11]. Jadi bisa dikatakan

penggunaan faktor eksposi yang tidak terlalu besar dapatkan hasil dosis efektif yang lebih kecil, tetapi dalam aplikasinya tidak dianjurkan menggunakan faktor eksposi yang lebih kecil lagi dikarenakan akan mempengaruhi hasil gambaran radiograf yang kurang baik dan tidak efektif dalam memberikan informasi medik. Jadi dianjurkan untuk pemerikssaan radiologi Mammografi disarankan lebih baik menggunakan faktor eksposi sekitar $27-30 \mathrm{kV}$ dan $250 \mathrm{~mA}$. Jadi berdasarkan hasil penelitian tersebut bisa didapatkan kesimpulan bahwa untuk pemeriksaan mammografi di instalasi radiologi parahita masih dinyatakan aman untuk masyarakat umum. Dikarenakan penggunaan sinar-X bersifat berbahaya sehingga pada pemeriksaan radiologi Mammografi bisa sesuai dengan prinsip ALARA (As Low As Reasonably Achieveble).

\section{KESIMPULAN}

Berdasarkan hasil penelitian dan pembahasan yang telah dilakukan dapat diperoleh kesimpulan bahwa nilai dosis ekivalen efektif yang terserap oleh organ tyroid 
Firmansyah, L., \& Anita, F. 2016. Pengukuran Dosis Efektif Organ Tyroid dan Mata Pada Pemeriksaan Mammografi. Journal of Sainstek 8(1): 31-37

pada pemeriksaan mammografi di Instalasi Radiologi Laboratorium Parahita yang menggunakan proyeksi rutin craniocaudal (CCL) dan mediolateral obelique (MLO) diketahui bahwa nilai dosis ekivalen efektif yang terpapar pada organ tyroid proyeksi medio lateral obelique didapatkan rata-rata adalah 0,001 mSv. Pada organ tyroid proyeksi cranio caudal didapatkan nilai ratarata adalah 0,001 $\mathrm{mSv}$. Hasil tersebut jauh lebih rendah bila dibandingkan dengan dosis toleransi yang ditetapkan oleh PERKA BAPETEN NO. 8 Tahun 2011. Nilai dosis efektif radiasi yang terserap oleh organ mata pada proyeksi medio lateral obelique didapatkan rata-rata adalah $0,012 \mathrm{mSv}$. Pada organ mata proyeksi cranio caudal didapatkan nilai rata-rata adalah 0,009 mSv. Hasil tersebut jauh lebih rendah bila dibandingkan dengan dosis toleransi yang ditetapkan oleh PERKA BAPETEN NO.8 Tahun 2011.

\section{DAFTAR KEPUSTAKAAN}

Yudistiro R. 2012. Evaluasi Fungsi Kelenjar Tiroid. Jakarta.

Sudibjo P. 1996. Anatomi Mata. Samarinda: Gunung Kelud.

Tjokronegoro A. 1982. Imunologi Diagnostik dan Terapi. Depok Jawa Barat : Fakultas Kedokteran Universitas Indonesia.

Pravasani A. 2012. Pengaruh Radioterapi Area Kepala dan Leher Terhadap pH Saliva. Skripsi. Semarang: Fakultas Kedokteran Universitas Diponegoro.

Dewiana. 2012. Analisa Dosis Serap Organ Kritis lensa mata pada terapi karsinoma nasofaring dengan pesawat sinar-X $6 \mathrm{mV}$. Skripsi. Jakarta: Fakultas Teknik dan Sains Universitas Nasional.

Anam C. 2013. Analisis Penerimaan Dosis Radiasi Di Organ Mata Pada Pemeriksaan Nasofaring Menggunakan Ct Scan. Skripsi. Semarang: Fakultas Sains dan Matematika Universitas Diponegoro.

Rudi, et al. 2012. Pengukuran Paparan Radiasi Pesawat Sinar x Di Instalasi Radiodiagnostik Untuk Proteksi Radiasi.
Unnes Physics Journal. Unnes Physics 1 (1) (2012). Semarang: Jurusan Fisika FMIPA Universitas Negeri Semarang Gunungpati.

Bushong S. 1988. Radiologic Science For Technologists, fourt edition. Washington : C.V. Mosby company.

PERKA BAPETEN NO 82011 Tentang Keselamatan Radiasi dalam penggunaan pesawat Sinar-X Radiologi Diagnostik dan Intervensional.

Akhadi M. 2000. Dasar - Dasar Proteksi Radiasi. Jakarta: Rineka Cipta. 41

Edwards C, Statkiewicz M dan Ritenour E. 1990. Perlindungan Radiasi Bagi Pasien dan Dokter Gigi. Jakarta: Widya Medika.

Krane K. 1992. Fisika Modern. Terjemahan oleh Wospakrik. H.J. Jakarta: Universitas Indonesia.

Beiser A. 1992. Konsep Fisika Modern. Jakarta: Erlangga.

Cember H. 1983. Pengantar Fisika Kesehatan. Edisi. Semarang: IKIP Semarang Press.

Suyati dan Akhadi M. 1998. Mengukur Kualitas Radiasi Keluaran Pesawat SinarX. Buletin Alara. 2(2): 7-12.

Kaplan I. 1979. Nuclear Physics, 2 nd edition. London: Addison-Wesley Publishing Company.

Dhahryan AM. 2009. Pengaruh Teknik Tegangan Tinggi terhadap Entrasce Skin Exposure (ESE) dan Laju Paparan Radiasi Hambur pada Pemeriksaan Abdomen. Berkala Fisika. 12 (1): 21-26.

Compagnone G, Pagan L dan Bergamini C. 2005. Comparison of Six Phantoms for Entrance Skin Dose Evaluation in 11 Standard X-Ray Examinations. Journal of Applied Clinical Medical Physics. 6(1):101-113.

Sharifat, Oyeleke OI. 2009. Patient Entrance Skin Doses at Minna and Ibadan for Common Diagnostic Radiological Examinations. Bayero Journal of Pure and Applied Sciences. 2(1): 1-5.

Waseso. 1998. Pengaruh Variasi Tegangan dan Arus Terhadap Kualitas Radiograf dan Dosis Yang Diterima Pasien pada Pemotretan Paru-Paru Proyeksi Postero 
Firmansyah, L., \& Anita, F. 2016. Pengukuran Dosis Efektif Organ Tyroid dan Mata Pada Pemeriksaan Mammografi. Journal of Sainstek 8(1): 31-37

Anterior (Study Kasus Di RSPAD “Gatot Soebroto"Jakarta). Skripsi. Semarang :Universitas Dipenegoro. 42.

Fahmi A, Firdausi KS, Budi WS. 2008. Pengaruh Faktor Eksposi pada Pemeriksaan Abdomen terhadap Kualitas Radiograf dan Paparan Radiasi menggunakan Computed Radiography. Berkala Fisika. 11 (4): 109- 118.
Sofyan H, Akhadi M, Prasetio H, Budiantari CT, Nuraeni N. 2012. Uji Karakteristik Dosimeter TL LiF:MG,Cu,P dan Dpsimeter OSL dan Pengembangan Metode Audit Dosimeter Fasilitas Radiologi untuk Peningtkatan Layanan dan Keselamatan Pasien Anak. Jakarta: Batan.

Pearce EC. 2009. Anatomi dan fisiologi untuk Paramedis. Jakarta: PT Gramedia Pustaka Utama. 